\title{
PENGAWASAN KEPALA INSPEKTORAT TERHADAP KINERJA APARATUR SIPIL NEGARA DIJABATAN STRUKTURAL INSPEKTORAT PROVINSI KALIMANTAN TENGAH
}

\author{
Oleh: INDAH SUBEKTI
}

\begin{abstract}
This study aims to determine the supervision of the Inspectorate's head on the performance of the Civil State Apparatus in the structural position of the Inspectorate of Central Kalimantan Province. Indicators used in measuring supervision Inspectorate head in this research are: Monitoring, Examination, Guidance and Direction, Discipline Action and Corrective Action.

This research was conducted by using qualitative methodology, by conducting interviews to the Chief Inspectorate. The data obtained is then processed by reduction steps, data presentation and conclusion, the number of informants interviewed are 5 persons, 1 (one) Head of Inspectorate, 2 (two) Head of Section in Structural Position and 2 (two) State Civil Apparatus in Structural Position.

Based on the results of research on the supervision of Inspectorate's head on the performance of State Civil Apparatus has been running but still not done with the maximum this is caused by every activity or work program is sometimes not submitted by each head of section and in accordance with supervision provisions seen from monitoring, examination, guidance and briefing, Disciplinary action and corrective action. Because basically State Civil Apparatus is the most important Human Resources for orgnanisasi in achieving its goals. In order for the objectives to be achieved then required supervision by the direct leadership.

Factors that support and inhibit the supervision of the head of Inpektorat on the performance of the State Civil Apparatus include the supporting factors that is in terms of recording procedures and reporting of work program activities as well as in terms of absence or attendance, inhibiting factors include pakewuh culture, limited time and in terms of aspects of Civil State Apparatus That is character difference.
\end{abstract}

\section{Kata Kunci: Pengawasan, kinerja, aparatur sipil negara, inspektorat}

\section{PENDAHULUAN}

Penelitian ini diarahkan kepada pengawasan kepala Inspektorat terhadap kinerja Aparatur Sipil Negara dijabatan struktural, pengawasan menjadi suatu unsur yang terpenting dalam manajemen organisasi, karena pengawasan merupakan tenaga penggerak bagi para bawahan agar dapat bertindak sesuai dengan apa yang telah direncanakan menurut aturan yang berlaku. Dengan adanya pengawasan yang baik maka suatu pekerjaan akan dapat berjalan dengan lancar dan dapat menghasilkan hasil kerja yang baik pula. selain itu, melalui pengawasan dapat 
dipantau berbagai hal yang dapat merugikan organisasi, antara lain kesalahankesalahan dalam pelaksanaan pekerjaan, kekurangan-kekurangan dalam pelaksanaan pekerjaan, kelemahan pelaksanaan dan cara kerjanya. Akan tetapi, pengawasan yang dilaksanakan pimpinan bukanlah untuk mencari-cari kesalahan, melainkan ditujukan agar rencana-rencana dapat dilaksanakan dengan sebaikbaiknya. Selain itu, dibutuhkan juga pengawasan yang berkelanjutan agar dapat menghasilkan dampak yang positif untuk perkembangan dan perubahan yang lebih baik.

Oleh karena itu, pimpinan ikut berperan serta dalam meningkatkan kinerja Aparatur Sipil Negara nya, pimpinan harus mampu menggerakkan dan mengarahkan ASN karena pimpinan bertanggung jawab terhadap keberhasilan serta kegagalan ASN. Apabila organisasi melaksanakan pengawasan secara baik sesuai dengan aturan yang telah ditetapkan dan dilaksanakan sesuai dengan tugas dan wewenang yang telah ditentukan, maka dengan sendirinya kinerja Aparatur Sipil Negara akan baik.

Begitu pentingnya arti kinerja, karena kelangsungan hidup organisasi sangat bergantung pada kinerja Aparatur Sipil Negara dalam melaksanakan tugas sesuai dengan tanggung jawabnya, oleh karena itu setiap organisasi selalu berupaya untuk meningkatkan kinerja ASN nya. berdasarkan latar belakang tersebut maka diperlukan pengawasan dari Kepala Inspektorat/pimpinan terhadap kinerja Aparatur Sipil Negara Khususnya di jabatan Struktural, agar tujuan Instansi dapat berjalan dengan lancar. Dengan adanya uraian kondisi inilah maka peneliti tertarik untuk melakukan penelitian yang berjudul: Pengawasan Kepala Inspektorat Terhadap Kinerja Aparatur Sipil Negara Dijabatan Struktural Inspektorat Provinsi Kalimantan Tengah

\section{TINJAUAN PUSTAKA}

\section{Pengawasan}

\section{Pengertian Pengawasan}

Dalam teori pengawasan menurut Kadarisman dalam buku Manajemen Pengembangan Sumber Daya Manusia menyatakan : "pengawasan adalah sesuatu tindakan membandingkan hasil pekerjaan dengan standar yang telah ditetapkan oleh organisasi”. Selanjutnya Saydam (2000:584-585)dalam buku Manajemen Pengembangan Sumber Daya Manusia mengemukakan pengawasan merupakan kegiatan yang di lakukan untuk mengendalikan pelaksanaan pekerjaan yang di lakukan, agar proses pekerjaan itu sesuai dengan hasi yang diinginkan. Sedangkan menurut Siagian (2001:52) masih dalam buku Manajemen Pengembangan Sumber Daya Manusia pengawasan adalah suatu proses pengamatan kegiatan operasional yang dimaksudkan untuk lebih menjamin bahwa penyelenggaraannya sesuai dengan rencana yang telah ditetapkan sebelumnya.

Jadi, secara umum pengawasan merupakan tindakan-tindakan perbaikan dalam pelaksanaan kerja agar supaya segala kegiatan sesuai dengan rencana yang telah ditetapkan, petunjuk-petunjuk dan instruksi-instruksi, sehingga tujuan yang telah ditentukan dapat tercapai. Selain itu, pengawasan juga merupakan fungsi yang 
mendukung keberhasilan pencapain tujuan yang telah ditetapkan. Kegiatan pengawasan terutama ditunjukan untuk menemukan secara dini kesalahan kesalahan atau penyimpangan-penyimpangan agar dapat segera diadakan perbaikan dan penelusuran kembali, sekaligus menyempurnakan prosedur, baik yang bersifat preventif, pengendalian maupun represif.

George R. Terry (1986) dalam buku Principles Of Management : DasarDasar Manajemen mengatakan bahwa : pengawasan juga berarti mendeterminasi apa yang di laksanakan, maksudnya mengevaluasi prestasi kerja dan apabila perlu, menerapkan tindakan-tindakan korektif sehingga hasil pekerjaan sesuai pekerjaan sesuai dengan rencana-rencana. Jadi, pengawasan dapat dianggap sebagai aktivitas untuk menemukan dan mengoreksi penyimpangan-penyimpangan penting dalam hasil yang dicapai dari aktivitas-aktivitas yang direncanakan.

Pengawasan tersebut praktisnya terdiri dari tindakan-tindakan :

a. Mencari keterangan tentang apa yang sedang dilaksanakan.

b. Membandingkan hasil-hasil dengan harapan-harapan yang menyebabkan timbulnya tindakan.

c. Menyetujui hasil-hasil atau menolak hasil-hasil dalam kasus mana perlu ditambahkan penambahan tindakan-tindakan perbaikan.

Dari beberapa penjelasan diatas maka dapat disimpulkan bahwa pengawasan merupakan tindakan-tindakan perbaikan dalam pelaksanaan kerja agar supaya segala kegiatan sesuai dengan rencana yang telah ditetapkan, petunjuk-petunjuk dan instruksiinstruksi, sehingga tujuan yang telah ditentukan dapat tercapai.

\section{Tujuan Pengawasan}

Tujuan utama dari pengawasan yaitu mengusahakan supaya apa yang direncanakan menjadi kenyataan. mencari dan memberitahu kelemahan-kelemahan yang dihadapi. Adapun tujuan pengawasan menurut (Sukarna, 1992:112) dalam buku Dasar-Dasar Manajemen antara lain :

1. Untuk jalannya pekerjaan apakah lancar atau tidak.

2. Untuk memperbaiki kesalahan-kesalahan yang dibuat oleh pegawai dan mengusahakan pencegahan agar supaya tidak terulang kembali kesalahan yang sama atau timbulnya kesalahan-kesalahan yang baru.

3. Untuk mengetahui apakah penggunaan budget yang telah ditetapkan dalam planning terarah kepada sasarannya dan sesuai dengan yang telah ditentukan.

4. Untuk mengetahui apakah pelaksanaan biaya telah sesuai dengan program seperti yang telah ditetapkan dalam planning atau tidak.

5. Untuk mengetahui hasil pekerjaan dengan dibandingkan dengan yang telah ditetapkan dalam rencana (standard), dan sebagai tambahan.

6. Untuk mengetahui apakah pelaksanaan kerja sesuai dengan prosedur dan kebijaksanaan yang telah ditentukan

\section{Indikator Pengawasan}

Menurut Pasaribu (2011:34-35) dalam buku Asas Manajemen pengawasan diukur berdasarkan indikatornya, yaitu : 
1. Pemantauan

Yaitu aktivitas memeriksa langsung yang dilakukan oleh pimpinan pada tempat dimana peristiwa terjadi dan dimana bawahan itu bertugas.

2. Pemeriksaan

Yaitu pengawasan yang dilakukan melalui pengamatan, pencatatan, penyelidikan dan penelahaan secara cermat dan sistematis serta melalui penilaian terhadap segala hal yang ada kaitannya dengan pekerjaan.

3. Bimbingan dan pengarahan

Yaitu aktivitas yang dilakukan oleh pimpinan dalam memberikan saran dan arahan terhadap pelaksanaan tugas.

4. Tindakan disiplin

Yaitu segala usaha yang dilakukan pimpinan terhadap bawahan dalam rangka memberikan sanksi bagi yang melanggar ketentuan yang berlaku.

5. Tindakan koreksi

Yaitu segala upaya yang dilakukan pimpinan untuk memperbaiki kesalahankesalahan atau penyimpangan yang dilakukan bawahan.

\section{Pengertian Kinerja}

Kinerja adalah aktivitas seseorang dalam melaksanakan tugas pokok yang dibebankan kepadanya, artinya yang diimplementasikan bahwa kinerja seseorang dihubungkan dengan tugas-tugas rutin yang dikerjakannya, dengan demikian bahwa kinerja atau performance merupakan hasil interaksi atau berfungsinya unsur-unsur motivasi kemampuan atau persepsi pada diri seseorang. Kinerja dalam sebuah organisasi merupakan salah satu unsur yang tidak dapat dipisahkan dalam suatu lembaga organisasi, baik itu lembaga pemerintahan maupun lembaga swasta. Kinerja berasal dari kata job performance atau Actual Performance yang merupakan prestasi kerja atau prestasi sesungguhnya yang dicapai seseorang. Kinerja adalah hasil atau tingkat keberhasilan seseorang dalam keseluruhan selama periode tertentu didalam melaksanakan tugas dibandingkan dengan berbagai kemungkinan, seperti standar hasil kerja, target atau sasaran atau kriteria yang telah ditentukan terlebih dahulu dan telah disepakati bersama.

Pengertian tersebut dapat disimpulkan bahwa kinerja sumber daya manusia adalah prestasi kerja atau hasil kerja (output) baik kualitas maupun kuantitas yang dicapai SDM persatuan periode waktu dalam melaksanakan tugas kerjanya sesuai dengan tanggung jawab yang diberikan kepadanya. Kinerja adalah hasil atau tingkat keberhasilan seseorang secara keseluruhan selama periode tertentu didalam melaksanakan tugas.

\section{METODOLOGI PENELITIAN}

Penelitian ini menggunakan jenis pendekatan kualitatif, yang mana proses penelitiannya dilakukan melalui wawancara dan observasi kepada narasumber. Menurut Taylor dan Bogdan penelitian kualitatif dapat diartikan sebagai penelitian yang menghasilkan data deskriptif mengenai kata-kata lisan maupun tertulis, dan tingkah laku yang dapat diamati dari orang-orang yang diteliti (Suyanto dan Sutinah, 2005:166). 
Untuk mendapatkan data-data penelitian, peneliti mengambil data dari lokasi kantor Inspektorat Provinsi Kalimantan Tengah. Dipilihnya Inspektorat Provinsi Kalimantan Tengah sebagai objek penelitian adalah karena lokasi tersebut merupakan tempat yang sesuai dengan permasalahan ataupun topik yang diangkat peneliti dalam melaksanakan penelitian. Teknik pengumpulan data menggunakan cara observasi, wawancara, dan dokumentasi. Analisis data dilakukan dengan model interaktif dari Miles dan Huberman.

\section{HASIL PENELITIAN}

Berdasarkan hasil dari penelitian saat ini maka ada beberapa hal yang ditemukan dalam pengawasan Kepala Inspektorat terhadap kinerja Aparatur Sipil Negara dijabatan struktural Inspektorat Provinsi Kalimantan Tengah.

Berdasarkan hasil penelitian yang peneliti lakukan dilapangan yang mengamati pengawasan yang dilakukan kepala Inspektorat terhadap kinerja Aparatur Sipil Negara, peneliti menemukan indikator-indikator dari pengawasan belum dilaksanakan dengan sepenuhnya mengingat masih terdapat kendala-kendala yang dihadapi dalam pengawasan terhadap kinerja Aparatur Sipil Negara seperti mekanisme pengganti pejabat pengawas kepala bagian saat perjalanan dinas belum jelas, laporan tertulis tentang aktivitas atau kegiatan program kerja terkadang tidak disampaikan oleh kepala bagian sehingga kepala Inspektorat harus turun langsung untuk menanyakan kegiatannya sudah sampai mana.

Faktor pendukung dari pengawasan yaitu bentuk pengawasan dengan prosedur pencatatan dan pelaporan dari hasil kerja atau kegiatan program kerja untuk melihat kinerja mereka sehingga ada diharapkan efisien dan efektif kinerja dari para Aparatur Sipil Negara, dan dengan laporan atau absen sehingga ada kedisiplinan dari para Aparatur Sipil Negara dalam hal kehadiran, Agar dapat menjalankan tugas dan tanggung jawabnya dengan sebaik-baiknya, Adanya tindakan koreksi oleh setiap kepala bagian guna mengetahui hasil kinerja dari para Aparatur Sipil Negara apakah sudah sesuai dengan standar yang telah ditetapkan atau masih belum mencapai standar tersebut, juga dilakukan untuk menghilangkan ketidaksesuaian yang telah ditemukan, agar tujuan dari pengawasan akan tercapai.

Faktor penghambat pengawasan yaitu adanya budaya pakewuh/sungkan yang mengakibatkan tidak sampai hati untuk menjatuhkan sanksi atau hukuman berat terhadap Aparatur Sipil Negara yang melakukan kesalahan. Terbatasnya waktu untuk melakukan pengawasan karena terlalu banyak volume pekerjaan yang dikerjakan oleh setiap kepala bagian. Dari aspek Aparatur Sipil Negara yaitu perbedaan karakter karena mereka seorang manusia yang tidak terlepas dari perbedaan karakter satu sama lain, ada yang pemarah, banyak bicara, ada juga yang mau menerima masukan dan saran bahkan ada yang sifatnya disiplin dan tidak disiplin.

\section{PENUTUP}

Kesimpulan

Berdasarkan penelitian maka dapat disimpulkan: 
a. Pelaksanaan Fungsi Legislasi DPRD Kota Palangka Raya dimulai dari penetapan Prolegda yang dilakukan oleh pihak DPRD, Prolegda tersebut ditetapkan melalui tahap inventarisasi masalah, persetujuan pimpinan DPRD dan merupakan kebutuhan daerah sehingga perlu untuk diatur. Kemudian dilakukan penyusunan Naskah Akademik dan Draf Raperda yang dilakukan oleh Panitia Kusus (Pansus) DPRD dan Tim Pemerintah Kota Palangka Raya yang bisa dibantu juga oleh kaum akademisi, budayawan, pakar-pakar yang menguasai materi Naskah Akademik dan Draf Raperda, dan tim dari Kementrian Hukum dan HAM. Kemudian Badan Musyawarah menjadwalkan rapat antara Pansus DPRD, Tim Pemko, dan Pimpinan DPRD untuk membahas Raperda yang telah memiliki Naskah Akademik dan Draf Raperda apakah sudah memiliki landasan hukum yang kuat dan tidak bertentangan dengan Undang-Undang. Setelah memenuhi ketentuan maka di tetapkanlah Raperda tersebut menjadi Perda. Sehingga Perda yang telah ditetapkan akan disosialisasikan oleh Pansus dan Sekretariat DPRD Kota Palangka Raya kepada masyarakat. Pelaksanaan Fungsi Legislasi DPRD Kota Palangka Raya masih belum optimal terutama dalam mengusulkan/menginisiatifkan Raperda, selain itu Raperda yang telah ditetapkan di dalam Prolegda atau Propem Perda tidak sepenuhnya selesai menjadi Perda. Sejauh ini pihak eksekutif atau Pemerintah Kota Palangka Raya lebih dominam dalam mengusulkan/menginisiatifkan Raperda. Hal tersebut dibuktikan dari penetapan Program Legislasi Daerah (Prolegda) Kota Palangka Raya pada tahun 2015, dari 21 (dua puluh satu) Raperda yang ditetapkan, 18 (delapan belas) Raperda merupakan usulan Pemerintah Kota dan 3 (tiga) Raperda merupakan inisiatif DPRD. Kemudian pada tahun 2016 Prolegda yang ditetapkan adalah sebanyak 29 (dua puluh sembilan) Raperda, 26 (dua puluh enam) Raperda merupakan usulan Pemerintah Kota dan 3 (tiga) Raperda merupakan inisiatif DPRD. Kemudian pada tahun 2017 Propem Perda yang ditetapkan adalah sebanyak 8 (delapan) Raperda, 5 (lima) Raperda merupakan usulan Pemerintah Kota dan 3 (tiga) Raperda merupakan inisiatif DPRD dan 5 (lima). Dalam pelaksanaan Fungsi Legislasi kewenangan dari DPRD secara tidak langsung seolah-olah dibatasi, hal tersebut dibuktikan dengan aturan bahwa DPRD Kota Palangka Raya hanya dapat menginisiatifkan Raperda yang bersifat mengatur atau penataan, sedangkan Pemerintah Kota Palangka Raya dapat mengusulkan Raperda yang bersifat mengatur dan memungut. Selain itu dalam hal pelaksanaan Fungsi Legislasi Undang-Undang yang berlaku seperti Undang-Undang Nomor 23 Tahun 2014 dan Undang-Undang Nomor 17 Tahun 2014 hanya mengatur bahwa DPRD memiliki salah satu fungsi yaitu legislasi, namun Undang-Undang tersebut tidak mengatur standar atau target minimal yang menjadi pedoman DPRD dalam menginisiatifkan Raperda untuk satu tahun pelaksanaan Fungsi Legislasinya. Hal tersebutlah yang mengakibatkan DPRD tidak memiliki pedoman atau target dalam menentukan jumlah Raperda.

b. Faktor-faktor yang menjadi penghambat dalam pelaksanaan Fungsi Legislasi DPRD Kota Palangka Raya meliputi: cara pandang latar belakang 
partai politik yang berbeda-beda, minimnya kehadiran Tim Pemko dan Pansus DPRD pada saat rapat pembahasan Raperda, evaluasi Raperda yang memakan waktu lama, landasan hukum Raperda belum cukup kuat, waktu penjadwalan pembahasan Raperda yang terlalu mepet, dan partisipasi masyarakat yang kurang responsif pada saat dilakukan sosialisasi dan konsultasi publik tentang Raperda yang sedang dirancang. Permasalahan tersebutlah yang mengakibatkan sebuah Raperda yang telah diprogramkan lambat jadi ataupun batal ditetapkan menjadi Peraturan Daerah (Perda). Kemudian pola hubungan antara DPRD dan Pemko dalam membentuk sebuah Perda dilakukan melalui kerjasama antara Pansus DPRD dan Tim Pemko. DPRD dan Pemko berkedudukan setara, merupakan mitra kerja, dan dapat saling melakukan checks and balances dalam pelaksanaan Otonomi Daerah. Meskipun memiliki kedudukan yang setara dalam pelaksanaan Otonomi Daerah, Pemerintah Kota Palangka Raya sejauh ini lebih dominan dalam mengusulkan/menginisiatifkan Raperda dibandingkan DPRD Kota Palangka Raya, oleh karena itu DPRD perlu untuk menginkatkan lagi usulan/inisiatif Raperda yang lebih berkualitas, kreatif, inovatif dan sesuai dengan keadaan di Kota Palangka Raya.

\section{Saran}

a. Peraturan Daerah yang dirancang atau dibuaat harus disesuaikan dengan perkembangan jaman, keadaan geografis dan sosial daerah serta mampu untuk mengatasi permasalahan, membangun daerah, dan mensejahterakan masyarakatnya.

b. Berbagai permasalahan yang dihadapi dalam pelaksanaan Fungsi Legislasi harus diminimalisir dan diatasi secepat mungkin serta dicari solusi yang terbaik agar permasalahan tersebut dapat diatasi.

c. Komunikasi dan singkronisasi antara DPRD Kota Palangka Raya dan Pemerintah Kota Palangka Raya harus dilakukan dengan baik agar dapat menciptakan pola hubungan yang harmonis tertuma dalam perancangan dan pembentukan sebuah Peraturan Daerah.

d. Keterlibatan atau partisipasi masyarakat harus ditingkatkan lagi jangan sampai Peraturan Daerah yang telah dibuat tidak diketahui atau dipahami oleh masyarakat Kota Palangka Raya, karena hal tersebut bisa mempengaruhi keberhasilan dari implementasi sebuah Peraturan Daerah.

e. Website DPRD Kota Palangka Raya perlu untuk diaktifkan lagi, dan berbagai produk hukum Kota Palangka Raya yang telah jadi mohon untuk dipublikasikan di website agar masyarakat dapat mengetahuinya.

\section{DAFTAR PUSTAKA}

Ariyanti, Teni Dwi. 2010. "Pelaksanaan Fungsi Legislasi Dewan Perwakilan Rakyat Daerah Kabupaten Ngawi.” Jurnal Ilmu Hukum. Universitas Sebelas Maret. 
Asshiddiqie, Jimly. 1994. Gagasan Kedaulatan Rakyat dalam Konstitusi dan Pelaksanaannya di Indonesia. Jakarta: Ichtiar Baru van Hoeve.

Budiardjo, Miriam. 2008. Dasar-Dasar Ilmu Politik. Jakarta: PT Gramedia Pustakan Utama.

Bungin, Burhan. 2001. Metodologi Penelitian Kualitatif. Jakarta: PT. Raja Grafindo Perkasa.

Djajaatmadja, Bambang Iriana. 2006. "Peranan Dewan Perwakilan Rakyat Daerah (DPRD) dalam Perencanaan Pembentukan Peraturan Perundang- Undangan di Daerah." Jurnal Legislasi Indonesia Volume 3 Nomor 1. Jakarta: Direktorat Jenderal Peraturan Perundang-Undangan Departemen Hukum dan Hak Asasi Manusia.

Etwiory, Endang Benselina . 2014. "Analisis Kinerja DPRD Kabupaten Maluku Tenggara dalam Era Otonomi Daerah." Jurnal Administrasi Publik dan Birokrasi Volume 1, Nomor 2. Universitas Terbuka.

Fachruddin. 2016. Membangun Otonomi Daerah Memperkuat NKRI. Jakarta: Serat Alam Media (SAM).

H.I, A. Rahman. 2007. Sistem Politik Indonesia. Yogyakarta: Graha Ilmu.

Hadi, Sutrisno. 1989. Penelitian Hukum Normatif-Empiris (Suatu Tinjauan Singkat). Jakarta: PT. Raja Grafindo Perkasa.

Jusmiati. 2013. "Pelaksanaan Fungsi Legislasi DPRD Kabupaten Kutai Timur Tahun 2009-2012." Jurnal Ilmu Pemerintahan. Universitas Mulawarman.

Keputusan Dewan Perwakilan Rakyat Daerah Kota Palangka Raya Nomor 26 Tahun 2014 Tentang Penetapan Program Legislasi Daerah Tahun 2015.

Keputusan Dewan Perwakilan Rakyat Daerah Kota Palangka Raya Nomor 17 Tahun 2015 Tentang Penetapan Program Legislasi Daerah Tahun 2016.

Keputusan Dewan Perwakilan Rakyat Daerah Kota Palangka Raya Nomor 17 Tahun 2016 Tentang Penetapan Program Pembentukan Perda Tahun 2017.

Koentjoroningrat. 1993. Metode-Metode Penelitian Mayarakat. Jakarta: PT Gramedia Pustakan Utama.

Manan, Bagir. 1994. Hubungan Pusat dan Daerah Menurut UUD 1945. Jakarta: Sinar Harapan.

Margaretha. 2014. "Peranan Dewan Perwakilan Rakyat Daerah (DPRD) dalam Pelaksanan Legislasi Di Kabupetan Kutai Barat." eJournal Administrative Volume 2, Nomor 3. Universitas Mulawarman Samarinda. 
Moleong, Lexy J. 2002. Metodelogi Penelitian Kualitatif. Bandung: PT Remaja Rosdakarya.

Nurcholis, Hanif. 2005. Teori dan Praktik Pemerintahan dan Otonomi Daerah. Jakarta: PT Grasindo.

Peraturan Menteri Dalam Negeri Republik Indonesia Nomor 80 Tahun 2015 Tentang Pembentukan Produk Hukum Daerah.

Sunarno, Siswanto. 2008. Hukum Pemerintahan Daerah Di Indonesia Jakarta: Sinar Grafika Offset.

Sutopo, H.B., 2002. Pengantar Penelitian Kualitatif: Dasar-Dasar Teoritis dan Praktis. Surakarta: Pusat Penelitian UNS.

Suyanto, Bagong \& Sutinah. 2005. Metode Penelitian Sosial Berbagai Alternatif Pendekatan. Jakarta: Kencana Prenadamedia Group.

Syafiie, Inu Kencana. 2011. Sistem Pemerintahan Indonesia. Jakarta: Rineka Cipta.

Undang-Undang Dasar Republik Indonesia Tahun 1945.

Undang-Undang Nomor 12 Tahun 2011 Tentang Pembentukan Peraturan Perundang-Undangan.

Undang-Undang Nomor 17 Tahun 2014 Tentang Majelis Permusyawaratan Rakyat, Dewan Perwakilan Rakyat, Dewan Perwakilan Daerah, Dan Dewan Perwakilan Rakyat Daerah.

Undang-Undang Nomor 23 Tahun 2014 tentang Pemerintah Daerah.

Wasistiono, Sadu dkk. 2009. Meningkatkan Kinerja DPRD. Bandung: Fokusmedia.

Widjaja, HAW. 2003. Titik Berat Otonomi Daerah. Jakarta: PT Raja Grafindo Persada. 